\title{
Differentiation of normative standards of budgetary appropriations for the maintenance of winter roads in the North of Russia
}

\author{
Elena Eduardovna Grigoryeva ${ }^{1, *}$ and Evgeniy Petrovich Grigoryev ${ }^{1}$ \\ ${ }^{1}$ North Eastern Federal University, 58, Belinsky street, Yakutsk, 677000, Russia
}

\begin{abstract}
The article discusses the results of a study of the issues of maintaining highways of regional and intermunicipal importance in the northern regions of Russia. A special role in the article is given to the category of highways as land and ice winter roads. In the hard-to-reach areas of the Arctic and North of Russia, winter roads are the most important element of the transport system. The maintenance and service of winter roads are the responsibility of the regional authorities. The existing issue of insufficient budgetary support for the maintenance of winter roads is, inter alia, associated with the imperfection of the methodology for calculating target norms of budgetary appropriations. The article presents well-reasoned facts and substantiation of the need to update the norms of budgetary appropriations for the maintenance of winter roads, taking into account difficult territorial natural and climatic conditions of work and transport accessibility of goods delivery. Recommendations are given for changing the methodology for calculating monetary costs for the maintenance of winter roads of regional and intermunicipal importance when determining the amount of appropriations from the budget of the constituent entities of the Russian Federation.
\end{abstract}

\section{Introduction}

When developing regional regulations and rules for calculating monetary costs for the maintenance, repair and thorough overhaul of highways of regional and intermunicipal importance, for determining the amount of appropriations from the budget of the constituent entities of the Russian Federation, the Government of the Russian Federation recommends relying on Decree No. 658of the Government of the Russian Federation "On the Standards of Financial Costs and the Rules for Calculating the Amount of Federal Budgetary Appropriations for Thorough Overhaul, Repairs and Maintenance of Federal Highways" dated May 30, 2017. The standards specified in the Decree are calculated taking into account the increase to 12 years of the turnaround time for the operation of federal highways with an improved type of coverage, subject to the requirements of technical regulations in terms of standard design loads. The general concept of developing standards allows for 5\% optimization of the standards for monetary costs for the maintenance and repair of highways [1].

This paper presents the results of a study of the regional characteristics of the northern regions of Russia affecting the maintenance of winter roads and provides a quantitative assessment and justification of the need to update the normative standards of budgetary appropriations, taking into account difficult territorial natural and climatic conditions of work and transport accessibility of goods delivery.

\section{Research methods}

The analysis of information on the ongoing work on thorough overhaul, current repairs and maintenance of highways of regional and intermunicipal importance of the Republic of Sakha (Yakutia) was carried out based on the provided source materials and as a result of processing information from other reliable sources.

Winter roads include seasonal highways with snow, ice and frozen ground and road surfaces. According to the classification, winter roads are subdivided into the following types: according to the duration of operation, according to their location on the ground (land, ice), as well as according to the duration of the season. In turn, regular and temporary winter roads, depending on the estimated annual traffic density or the estimated traffic intensity, are divided into three categories.

When studying the methodological basis of the research issue, a variety of scientific works [2-5] related to various methods and methodological approaches to the calculation of standards for monetary costs for the maintenance of highways was considered. For example, I.A. Kurbatov [6] proposed a methodology, where the calculation of the standards of compensation from the main expenditure components is carried out on the basis of determining the cost of carrying out transportation and the cost of maintaining and developing the road network.

* Corresponding author: elena.grigoreva80@mail.ru 
The author attributes the costs of purchasing a car and operating and repair costs to the components of transport costs. The use of compensation standards makes it possible to finance highways. Egorova T.P. made efforts to adapt standard models of vehicles for operation under Arctic conditions and to introduce cross-country transport machines have unraveled a number of challenging issues in the complex cycle of developing a vehicle and delivering it to consumer [7-9].

\section{Studying application of territorial coefficient in calculation rules}

In the study, a sample of the most costly regions of the Russian Federation [10-12] was made, including the Far Eastern Federal District, using the territorial coefficient of 1.59 for maintenance, 1.68 for repairs, and 1.68 for thorough overhaul.

The results of a comparative analysis of the current regulatory acts of the constituent entities of the Russian Federation that are part of the Far Eastern Federal District show that some constituent entities of the Russian Federation continue using Decree of the Government of the Russian Federation approved in 2008-2010 when calculating the standards for financial costs and the size of budgetary appropriations for thorough overhaul, repair and maintenance of regional and intermunicipal highways.

The results of a comparative analysis of the normative financial costs of the current normative acts of the constituent entities of the Russian Federation included in the Far Eastern Federal District are presented in Table 1.

Analyzing the range of asymmetry of the differentiation of costs of maintaining highways of regional and intermunicipal importance in the constituent entities of the Russian Federation in the Far Eastern Federal District in comparison with the Russian Federation as a whole, it can be argued that the values of the standards of financial costs for maintenance differ from 0.28 to 1.9 times with the standard coefficient of differentiation of 1.68 for the Far Eastern Federal District (according to the Decree of the Government of the Russian Federation No. 658). At the same time, low indicators (below 1) do not indicate that the cost of work in the region is lower than the average in Russia, but indicate the unreliability of this standard of the real cost of work in the region, which leads to underestimated insufficient values of budgetary appropriations.

Insufficient funding for repair and thorough overhaul of the regional road network of the Republic of Sakha (Yakutia) causes the following negative consequences (Table 2):

- It does not allow maintaining the proper technical condition of highways and leads to a decrease in the level of road maintenance.

- A low level of road maintenance leads to an increase in the number of accidents, including due to shortcomings in the transport and operational state of the road network sections.
- The limited financial security of work leads to nonobservance of turnaround times with their required increases, taking into account Rules No. 658.

Table 1. Information on the financial costs of maintenance of regional and intermunicipal roads as of 01.01.2020.

\begin{tabular}{|c|c|c|c|c|c|c|}
\hline \multirow[t]{3}{*}{ No } & \multirow{3}{*}{$\begin{array}{l}\text { Subjects } \\
\text { of the } \\
\text { Russian } \\
\text { Federatio } \\
\text { n }\end{array}$} & \multicolumn{4}{|c|}{$\begin{array}{c}\text { Financial cost standards per } 1 \\
\text { km of category } V \text {, (RUB thous.) }\end{array}$} & \multirow{3}{*}{$\begin{array}{l}\text { Diffe } \\
\text { renti } \\
\text { ation } \\
*\end{array}$} \\
\hline & & \multirow[b]{2}{*}{$\begin{array}{l}\text { Year } \\
\text { of } \\
\text { adopt } \\
\text { ion } \\
\text { of } \\
\text { stand } \\
\text { ards }\end{array}$} & \multirow[b]{2}{*}{$\begin{array}{l}\text { The } \\
\text { standa } \\
\text { rd is } \\
\text { appro } \\
\text { ved in } \\
\text { prices } \\
\text { for X } \\
\text { year }\end{array}$} & \multicolumn{2}{|c|}{ Content } & \\
\hline & & & & $\begin{array}{l}\text { in } \\
\text { approv } \\
\text { al } \\
\text { prices }\end{array}$ & $\begin{array}{c}\text { The } \\
\text { same } \\
\text { in } \\
2019 \\
\text { prices }\end{array}$ & \\
\hline 1 & $\begin{array}{c}\text { Republic } \\
\text { of } \\
\text { Buryatia }\end{array}$ & 2018 & 2016 & 547 & 611 & 0.67 \\
\hline 2 & $\begin{array}{l}\text { Republic } \\
\text { of Sakha } \\
\text { (Yakutia) }\end{array}$ & 2009 & 2008 & 319 & 527 & 0.58 \\
\hline 3 & $\begin{array}{c}\text { Zabaykals } \\
\text { ky Krai }\end{array}$ & 2018 & 2017 & 641 & 683 & 0.75 \\
\hline 4 & $\begin{array}{l}\text { Kamchatk } \\
\text { a Krai }\end{array}$ & 2011 & 2010 & 900 & 1595 & 1.76 \\
\hline 5 & $\begin{array}{l}\text { Primorsky } \\
\text { Krai }\end{array}$ & 2012 & 2014 & 336 & 469 & 0.52 \\
\hline 6 & $\begin{array}{l}\text { Khabarov } \\
\text { sk region }\end{array}$ & 2009 & 2009 & 526 & 1078 & 1.19 \\
\hline 7 & $\begin{array}{l}\text { Amur } \\
\text { region }\end{array}$ & 2018 & 2020 & 321 & 313 & 0.34 \\
\hline 8 & $\begin{array}{l}\text { Magadan } \\
\text { Region }\end{array}$ & 2018 & 2018 & 466 & 488 & 0.54 \\
\hline 9 & $\begin{array}{c}\text { Sakhalin } \\
\text { Region }\end{array}$ & 2011 & 2007 & 709 & 1734 & 1.91 \\
\hline 10 & $\begin{array}{c}\text { Jewish } \\
\text { Autonom } \\
\text { ous } \\
\text { Region } \\
\end{array}$ & 2008 & 2013 & 181 & 251 & 0.28 \\
\hline 11 & $\begin{array}{c}\text { Chukotka } \\
\text { Autonom } \\
\text { ous } \\
\text { District }\end{array}$ & 2010 & 2011 & 709 & 1100 & 1.21 \\
\hline 12 & $\begin{array}{c}\text { Russian } \\
\text { Federatio } \\
\mathrm{n}(\mathrm{RF})\end{array}$ & 2017 & 2016 & 806 & 908 & 1.00 \\
\hline 13 & $\begin{array}{c}\text { Far } \\
\text { Eastern } \\
\text { Federal } \\
\text { District }\end{array}$ & 2017 & 2016 & 1282 & 1432 & 1.58 \\
\hline
\end{tabular}

Explanation: the index-deflator of consumer prices and investments in fixed assets corresponds to the data of Rosstat posted on the official website *Differentiation of maintenance costs in comparison with the RF (prices in 2019)

Let's consider one of such regions, the Republic of Sakha (Yakutia). A regional features of the structure of length of regional and intermunicipal roads in Yakutia are as follows: low transport accessibility, significant distances between 36 municipal districts (especially between the Arctic regions) and high remoteness from federal highways, which justifies the need to maintain land and ice seasonal (winter) roads. A characteristic 
feature of the Republic of Sakha (Yakutia) is that $73 \%$ of the regional road network is occupied by seasonal roads (35\% ice, $38 \%$ land). Consequently, the presence of a significant share of regional and intermunicipal winter roads justifies the need to include separate coefficients in the rules for calculating the standards of financial costs, taking into account the differentiation of the cost of work on winter roads [13-15].

Table 2. Information on the financial costs of repair and overhaul of regional and intermunicipal roads as of 01.01.2020.

\begin{tabular}{|c|c|c|c|c|c|}
\hline \multirow[t]{3}{*}{ No } & \multirow{3}{*}{$\begin{array}{c}\text { Subjects of the } \\
\text { Russian } \\
\text { Federation }\end{array}$} & \multicolumn{4}{|c|}{$\begin{array}{l}\text { Financial cost standards per } 1 \\
\text { km of category } V \text {, (RUB thous.) }\end{array}$} \\
\hline & & \multicolumn{2}{|c|}{ Repairs } & \multicolumn{2}{|c|}{ Overhaul } \\
\hline & & $\begin{array}{c}\text { in } \\
\text { appro } \\
\text { val } \\
\text { price } \\
\text { s }\end{array}$ & $\begin{array}{c}\text { The } \\
\text { same } \\
\text { in } \\
2019 \\
\text { prices }\end{array}$ & $\begin{array}{l}\text { in } \\
\text { approv } \\
\text { al } \\
\text { prices }\end{array}$ & $\begin{array}{c}\text { The } \\
\text { same } \\
\text { in } \\
2019 \\
\text { prices }\end{array}$ \\
\hline 1 & $\begin{array}{l}\text { Republic of } \\
\text { Buryatia }\end{array}$ & 4738 & 5216 & 12008 & 13221 \\
\hline 2 & $\begin{array}{c}\text { Republic of } \\
\text { Sakha (Yakutia) }\end{array}$ & 3798 & 6270 & 7150 & 11804 \\
\hline 3 & $\begin{array}{l}\text { Zabaykalsky } \\
\text { Krai }\end{array}$ & 4704 & 4414 & 10396 & 9754 \\
\hline 4 & Kamchatka Krai & 4651 & 3996 & 14699 & 12629 \\
\hline 5 & Primorsky Krai & 2578 & 2278 & 11627 & 10274 \\
\hline 6 & $\begin{array}{c}\text { Khabarovsk } \\
\text { region }\end{array}$ & 3539 & 2858 & 11985 & 9677 \\
\hline 7 & Amur region & 2634 & 2571 & 8242 & 8044 \\
\hline 8 & $\begin{array}{c}\text { Magadan } \\
\text { Region } \\
\end{array}$ & 3122 & 3569 & 9867 & 11278 \\
\hline 9 & Sakhalin Region & 3665 & 2118 & 11583 & 6692 \\
\hline 10 & $\begin{array}{c}\text { Jewish } \\
\text { Autonomous } \\
\text { Region }\end{array}$ & 2806 & 1495 & 9090 & 4841 \\
\hline 11 & $\begin{array}{l}\text { Chukotka } \\
\text { Autonomous } \\
\text { District }\end{array}$ & 3198 & 6130 & 9506 & 18221 \\
\hline 12 & $\begin{array}{c}\text { Russian } \\
\text { Federation (RF) }\end{array}$ & 4738 & 5169 & 12008 & 13099 \\
\hline 13 & $\begin{array}{c}\text { Far Eastern } \\
\text { Federal District }\end{array}$ & 7960 & 8940 & 20173 & 22658 \\
\hline
\end{tabular}

Explanation: the index-deflator of consumer prices and investments in fixed assets corresponds to the data of Rosstat posted on the official website.

In the Republic of Sakha (Yakutia), the length of the regional road network in 2019 was $13,079.09 \mathrm{~km}$ with a decrease of $0.02 \%$ or $23.45 \mathrm{~km}$ as compared to 2018 . The base normative standard is applied in prices of 2008, taking into account the investment deflator index by planning years to the base one in accordance with calculation rules No. 352. It should be borne in mind that the investment deflator index for years does not fully take into account the dynamics of the growth in the cost of goods and services (work) in the region; therefore it is proposed using the consumer price deflator index for the region in the calculation rules for road maintenance, as well as it is used in similar calculation rules by other constituent entities of the Russian Federation.
As a result of data statistical processing, an average of $24.7 \%$ of the normative need was allocated for the maintenance of regional and intermunicipal highways in the Republic of Sakha (Yakutia) in 2019, which is lower than the level for the Russian Federation as a whole $(29.6 \%)$. This does not allow maintaining the proper technical condition of the roads. Consequently, the full scope of work on the maintenance of the regional road network is not being carried out. In fact, in 2019, 61\% of the regional road network of the Republic of Sakha (Yakutia) financed by their road fund was covered, where maintenance work was carried out with an average cost of RUB 157,700 per $1 \mathrm{~km}$, which is $45 \%$ lower than the national level (RUB 288,100).

In the Arctic zone of the Republic of Sakha (Yakutia), regional and intermunicipal highways are assigned on the basis of the right of operational management to the Arctic Roads Public Enterprise of the Republic of Sakha (Yakutia). In 2019, 5,708.61 km of regional and intermunicipal highways were assigned to the Arctic Roads Public Enterprise of the Republic of Sakha (Yakutia), whereof $92 \%$ are seasonal roads, including: $44 \%$ land roads and $48 \%$ ice roads. The actual cost of maintaining of highways of regional and intermunicipal importance in the Arctic zone of the Republic of Sakha (Yakutia) assigned to the Arctic Roads Public Enterprise of the Republic of Sakha (Yakutia) was RUB 102.38 per $1 \mathrm{~km}$, covering 93\% of the total fixed length of highways. Consequently, the real cost of maintaining of $1 \mathrm{~km}$ of highway of the regional road network of the Republic of Sakha (Yakutia) is three times lower than the normative one.

\section{Approaches to winter roads coefficient development}

In order to determine a methodological approach to calculating the amount of budgetary appropriations for the maintenance of winter roads of regional and intermunicipal importance of the Republic of Sakha (Yakutia), an analysis of the practical experience of the northern regions in the development of rules for calculating financial costs for the maintenance of seasonal (winter) highways, including Chukotka Autonomous District, Yamalo-Nenets Autonomous Area, Sakhalin Region and Krasnoyarsk Territory was carried out.

In Sakhalin Region, in Decree No. 1042 of the Administration of Yuzhno-Sakhalinsk City dated June 3, 2010, when establishing standards for financial costs for the maintenance of common use highways of local significance, winter roads are allocated to the group of non-category roads which are equated to the 5th category.

In Yamalo-Nenets Autonomous Area, all winter roads of regional or intermunicipal importance are equated to the 3rd category. The normative standard in the amount of RUB 392,700 (at the price level of 2017) is established by separate Resolution No. 1092-ח of the Government of Yamalo-Nenets Autonomous Area dated October 18, 2017. When determining the amount of 
budgetary appropriations for the maintenance of winter highways in Yamalo-Nenets Autonomous Area, the level of budgetary provision of the regional budget expenditures for the maintenance of winter highways in the corresponding year is taken into account as a percentage $(\mathrm{Kbp})$ and is calculated according to formula 1.

$$
\mathrm{A}_{\text {maintaince }}=\mathrm{H} * \mathbf{\mathrm { Lj }} *\left(\mathrm{~K}_{\mathrm{bp}} / 100\right)
$$

where $A_{\text {maintaince }}$ is the amount of appropriations from the district budget for the maintenance of winter highways (RUB thous.);

$\mathrm{L}$ is the length of winter highways $(\mathrm{km})$;

$\mathrm{K}_{\mathrm{bp}}$ is the level of budgetary provision of the regional budget expenditures for the maintenance of winter highways in the corresponding year (\%).

In Chukotka Autonomous District, the distribution of winter roads categories is applied taking into account the arrangement of ice crossings along the river or sea, as well as the costs of preparatory work for winter roads opening (before winter operation). Application of the methodological approach of Chukotka Autonomous District for calculating the amount of appropriations from the budget of the Republic of Sakha (Yakutia) for the maintenance, thorough overhaul and repair of highways of the corresponding category (by type of coverage) and winter roads with extended service life has a drawback in the absence of accounting the coefficient of territorial differentiation of cost of work (services) by municipal districts. Thus, the considered technique needs follow-up revision in order to be used in the Republic of Sakha (Yakutia).

In Krasnoyarsk Territory, the methodological approach is used to establish the standard of monetary costs for the maintenance, repair and thorough overhaul of highways according to the corresponding category (by type of coverage) and taking into account traffic intensity (number of cars per day). The distribution of standards for the 1st, 2nd and 3rd categories is applied to winter roads.

Krasnoyarsk Territory, like the Republic of Sakha (Yakutia), is characterized by a significant area of the region's territories and an impressive length of regional and intermunicipal roads. The regions determine the presence of intraregional differentiation and asymmetry in rise in goods and works (services) prices, depending on the municipal district transport accessibility. Thus, the inclusion of the territorial coefficient in the calculation, which takes into account the differentiation of the cost of road maintenance by municipal districts and urban districts, is reasonable and necessary.

In the Republic of Sakha (Yakutia), the normative standards for monetary costs for the maintenance, repair and thorough overhaul of roads of regional and intermunicipal importance of the 4th category, and not the 5th category as in other constituent entities of the Russian Federation, are established on the basis of Decree No. 352 of the Government of the Republic of Sakha (Yakutia) dated August 27, 2009.

In this methodology, winter roads are divided into two categories, but a reduction factor is applied for the northern regions that takes into account the seasonality: 0.96 for overland winter roads and 0.66 for ice winter roads. At the same time, 15 out of 36 municipal districts located in the Arctic and eastern zones of the Republic of Sakha (Yakutia) belong to the northern regions.

\section{Conclusion}

Based on the results obtained, it is recommended to apply following proposals in the rules for calculating monetary costs for the maintenance, repair and thorough overhaul of highways of regional and intermunicipal importance when determining the amount of appropriations from the budget of the Republic of Sakha (Yakutia):

1. The applied normative standard for the maintenance, repair and thorough overhaul of highways in the Republic of Sakha (Yakutia) approved in 2008, even taking into account the deflator index of investments in fixed assets, is two times lower than the average in Russia. It indicates the unreliability of this standard as for the real cost of work in the region. This leads to underestimated insufficient values of budget allocations. It is necessary to bring this normative standard to a level not lower than 1.68 than the average in Russia.

2. The presence of a significant share of winter roads of regional and intermunicipal importance justifies the need to include separate coefficients considering the differentiation of cost of work on winter roads in the rules for calculating the standards of financial costs.

3. In connection with the high intraregional differentiation of cost of construction and repair work, it is proposed to use an approach to the distribution of budgetary appropriations in 36 municipal districts, taking into account transport accessibility to nearby transport hubs, natural and climatic conditions and the type of road surface. Therefore, it is recommended to include the following additional increasing factors in the calculation rules: the coefficient of road natural and climatic zone and the coefficient of transport accessibility.

4. The deflator index of investments by years does not fully take into account the dynamics of cost growth rates for goods and services (work) in the region. Therefore it is proposed to use the deflator index of consumer prices for the region in the calculation rules for road maintenance, just as it is used in similar calculation rules for other constituent entities of the Russian Federation.

\section{Acknowlegements}

This work was prepared within the framework of the project on the state task of the Ministry of Science and Higher Education of the Russian Federation titled «The Patterns of Spatial Organization and Spatial Development of Socio-Economic Resource Systems of the Northern Region» (No. FSRG-2020-0010). 


\section{References}

1. E.A. Latkina, T.F. Matyushenko, Roads and bridges 2(38), 1 (2017)

2. S.V. Fedotov, T.F. Matyushenko, Roads and bridges 2(18), 11-20 (2007)

3. V.V. Gasilov, M.A. Preobrazhensky, S.S. Zamchalova, M.A. Shibaeva, Science and technology in the road industry 2 , 10-12 (2002)

4. A.S. Eremeeva, News of higher educational institutions. Series: Economics, Finance and production management 2(12), 3-9 (2012)

5. V.K. Apelin, About inter-repair terms of capital repairs of highways in modern conditions of financing Roads and bridges 18(2), 20-29 (2007)

6. I.A. Kurbatov, Bulletin of the Moscow automobile and road state technical University (MADI) 3(22), 60-63 (2010)

7. T.P. Egorova, A.M. Delakhova, Proceedings of the International Conference "Aviamechanical engineering and transport" (AVENT 2018) Series:Advances in Engineering Research 158, 123-129 (2018)

8. T.P. Egorova, A.M. Delakhova, Smart Innovation, Systems and Technologies 138, 272-282 (2020)

9. T.P. Egorova, A.M. Delakhova, IOP Conference Series: Materials Science and Engineering 632(1), 012029 (2019)

10. V.N. Leksin, B.N. Porfiryev, Economy of Region, 3, 641-657 (2017)

11. V.N. Borisov, O.V. Pochukaeva, Studies on Russian Economic Development 27(2), 159-165 (2016)

12. P.V. Gulyaev, Gornyi Zhurnal 12, 23-26 (2018)

13. E.E. Grigoryeva, IOP Conference Series: Earth and Environmental Science 302(1), 012138 (2019)

14. V.V. Nikiforova, E.R. Romanova, E.E. Grigorieva, Gornyi Zhurnal 3, 41-46 (2018)

15. V.V. Nikiforova, IOP Conference Series: Materials Science and Engineering 753(7), 072008 (2020) 